\title{
A STUDY ON THE IMPACT OF ICT ON TEACHING IN HIGHER EDUCATION WITH REFERENCE TO INDIA
}

\author{
Dr. Santhosh Kumar Assistant Professor, Dept.of Management, Government First Grade College \\ A. V. \\ For Women, Old M.C.Road, Maddur-571428, Mandya District.

ABSTRACT Education has been an important instrument for social and economic transformation in India. Presently, higher education in India is experiencing a major transformation in terms of access, equity and quality. This transition is highly influenced by the swift developments in Information and Communication technology (ICT) all over the world. Introduction of ICT in higher education has profound implications for the education process especially in dealing with key issues of access, equity, management, efficiency, pedagogy and quality of teaching. At the same time, Optimal utilization of opportunities arising due to diffusion of ICT in higher education system presents a profound challenge for institutions. Quality education ushers in a lifetime of opportunity, which helps build a strong and diverse citizenry to work and live in an increasingly competitive world. Higher education provides the competencies that are required in different spheres of human activity. Knowledge is the driving force in the rapidly changing globalized economy and society.

In this backdrop, the study addresses the opportunities and challenges posed due to integration of ICT in various aspects of higher education in the present scenario and it's impact on teaching in India. The role of ICT in improving the quality of higher education was also explored.

KEYWORDS : Higher Education, Information and Communication Technology (ICT), Pedagogy, Competencies,

\section{INTRODUCTION TO THE STUDY}

Education is recognized as one of the critical elements of the national development effort and Higher education, in particular, is of vital importance for the nation as it is a powerful tool to build a knowledge-based society. At any given time, higher education has been a key factor for its ability to change and to induce progress in the society. The vision is to realize the human resource potential to its fullest in the higher education sector with equity and inclusion. A quality education ushers in a lifetime of opportunity, which helps build a strong and diverse citizenry to work and live in an increasingly competitive world. Education is one of the most powerful instruments for reducing poverty and inequality. It is equally important to enhance the competitiveness in the global economy. Knowledge is the driving force in the rapidly changing globalized economy and society. Education in general and higher education in particular, is a highly nation specific activity, determined by national culture and priorities.

The Indian higher education system has emerged as one of the largest in the world, with 14.6 million students enrolled in more than 31,000 institutions. The number of institutions has grown at a CAGR of $11 \%$. Education is essential for the growth and prosperity of both a nation and society. Apart from primary and secondary education, higher education is the main instrument for development and transformation. Higher education has the omnipotent role of preparing future leaders for different spheres of life-social, economic, political, cultural, scientific and technological. According to UNESCO Report on Education in the 2lst century, Higher Education is the mandate to bridge the knowledge gap between countries and communities, enriching dialogues between people culture; international linking and net-working of ideas, research and technologies. Thus, Higher education provides the competencies that are required in different spheres of human activity, ranging from administration to agriculture, business, industry, health and communication and extending to the arts and culture. According to Dr. Babasaheb Ambedkar (Bombay, Legislative council Debate,27 july1927), "The university is a machinery whereby education facilities are provided to all those who are intellectually capable of using those facilities to be the best advantages but who cannot avail themselves of those facilities for want of funds or for other handicaps in life". The people in university education shape the behavior; minds and the social and human values of the student community. Effective use of technology can motivate students, make our classes more dynamic and interesting and renew teacher enthusiasm as they learn new skills and techniques. Technology is also helping the students to understand any abstract concepts clearly. Information and Communication Technology (ICT) has become an integral part of today's teaching learning process. The integration of ICT in teaching in general and teacher education in particular is the need of the day. The use of ICT can make substantial changes both for teaching and training mainly in two ways; firstly, the rich representation of information changes learner's perception and understanding of the context. Secondly; the vast distribution and easy process access to information can change relationships between teachers and taught. ICT can also provide powerful support for educational innovation. In the last few decades, we have seen an increasing number of youngsters gaining access to higher education. This phenomenon reflects a trend at a global level, which is largely due to the democratization and development of societies, improvement of living conditions and structures, demand for a more highly qualified performance both in professions and citizenships. Hence we have witnessed a change both in terms of quality of teaching and student population, reflected in the gradual loss of the elitist and formal character of higher education through the admission of individuals from all social classes. The emancipatory and transformative potentials of ICT in higher education in India have helped increase the country's requirement of higher education through part- time and distance learning schemes. It can be used as a tool to overcome the issues of cost, less number of teachers and poor quality of education as well as overcome time and distance barriers.

\section{REVIEW OF LITERATURE}

Review of literature defined and guided this study by focusing on the chosen area of the study i.e. Impact of ICT on teaching in higher education. It provided a comprehensive perspective
Submitted : $07^{\text {th }}$ July,2019
Accepted : 24 ${ }^{\text {th }}$ July,2019
Publication : $15^{\text {th }}$ November, 2019 
of past and current research in the area chosen for the study. The review revealed studies that addressed the importance of usage of ICT in teaching in higher education. The main goal of this chapter was to provide historical information about the importance of ICT in higher education.

Higher education provides the competencies that are required in different spheres of human activity, ranging from administration to agriculture, business, industry, health and communication and extending to the arts and culture (Power, 2002). As per an estimate in FICCI-Ernst \&Young report 2010, expenditure on higher education is going to increase to Rs. $155,015 \mathrm{Cr}$ and requires an investment of Rs. 360,640 crores (\$ $76 \mathrm{bn}$ ) by 2020 to create the additional capacity. We have witnessed a change both in terms of quality of teaching and student population, reflected in the gradual loss of the elitist and formal character of higher education through the admission of individuals from all social classes (Soares and Almeida, 2002). According to UNESCO Report on Education in the 21st century, Higher Education is the mandate to bridge the knowledge gap between countries and communities, enriching dialogues between people culture; international linking and networking of ideas, research and technologies. The emancipatory and transformative potentials of the ICT in higher education in India has helped increase the country's requirement of higher education through part- time and distance learning schemes. It can be used as a tool to overcome the issues of cost, less number of teachers and poor quality of education as well as overcome time and distance barriers (MC Gorry, 2002). The various kinds of ICT products available and having relevance to education, such as teleconferencing, email, audio conferencing, television lessons, radio broadcasts, interactive radio counselling, interactive voice response system, audiocassettes and CD ROMs have been used in education for different purposes. ICT also allows for the creation of digital resources like digital libraries where students, teachers and professionals can access research material and course material from any place at any time (Bhattacharya and Sharma, 2007). E-education can provide access to the best gurus and the best practices or knowledge available (UNESCO, 2002). The demand for higher education is expected to rise steeply in the forthcoming years under these influences. ICTs lend themselves as an ideal mechanism to bridge this gap by complementing both formal education system as well as distance learning systems. Focus of instruction is now on education programs/practices that promote competency and performance. Such curricula tends to require access to variety of information sources, information forms and types; student centered learning settings based on information access and inquiry; learning environments centered or problem-centered and inquiry-based activities, authentic settings and examples; and teachers as coaches and mentors rather than content experts (Neeru, 2009).

Introducing ICT systems for teaching in developing countries has a particularly high opportunity cost because installing them is usually more expensive in absolute terms than in industrialized countries whereas, in contrast, alternative investments (e.g. buildings) are relatively less costly. The four most common mistakes in introducing ICT into teaching are installing learning technology without reviewing student needs and content availability; imposing technological systems from the top down without involving faculty and students; using incppropriate content from other regions of the world without customizing it appropriately and producing low quality content that has poor instructional design and is not adapted to the technology in use (UNESCO, 2009). Holding onto the aforesaid traditional way of knowledge dissemination is to assume that there is a one-size-fit all approach in teaching and learning, a presumption that is further from reality (Koller, 2012). Watson, 2001 spearheads placing pedagogy before technology. Indeed, stimulating and strengthening the College's academic core should be the primary focus. According to the India Labor Report (2011) by Team Lease Services, During India's independence, there were 20 universities and 591 colleges while students enrollment at the tertiary level of education was 0.2 million. While focusing about the growth in student enrolment, the University Grants Commission (UGC report) stated that, in 1950, the total number of students enrolled in higher educational institutions was $3,97,000$. The growth witnessed was steady till 2001 and stood at $83,99,000$ but saw an unprecedented surge in the next 10 years. In 2010-11 it was $1,69,75,000$, a figure that had almost doubled in the last decade. The Team Lease Services study clarifies that despite the enrollment rate improving, India still lags behind its international counterparts. The higher education Gross Enrolment Ratio (GRE) of India is $13.5 \%$. This is much below the world average of $24 \%$, two thirds of that of developing countries (18\%) and way behind that of developed countries (58\%). Use of ICT in education develops higher order skills such as collaborating across time and place and solving complex real world problems (Bottino, 2003). It improves the perception and understanding of the world of the student. Thus, ICT can be used to prepare the workforce for the information society and the new global economy (Kozma, 2005). The main goals of ICT adoption in the education field are reducing costs per student, making education more affordable and accessible, increasing enrollments, improving course quality and meeting the needs of local employers (Ozdemir and Abrevaya, 2007). India is making use of powerful combination of ICTs such as open source software, satellite technology, local language interfaces, easy to use human-computer interfaces, digital libraries etc. with a longterm plan to reach the remotest of the villages. Community service centers have been started to promote e-learning throughout the country (Bhattacharya and Sharma, 2007).

\section{OBJECTIVES OF THE STUDY}

The following are the objectives of the study:

- To study the impact of ICT on Teaching in Higher Education with reference to India.

- To analyze the opportunities and challenges of integration of ICT in higher education.

- To explore the role of ICT in improving the quality of higher education.

\section{RESEARCH METHODOLOGY}

Research design is a strategy or a plan used in conducting research to obtain data that will respond to research questions. Before selecting a research design, a research problem has to be formulated on which the research design will be based. The design used for this study is an exploratory research design. The major emphasis in such studies is the discovery of ideas and insights to provide opportunity for considering different aspects of a problem under study. Methodology addresses the process of the research, describing how the research will be accomplished. The study is an exploratory research study. The methodology used for the study included the survey of concerning literature which helps a researcher to review and build upon the work already done by others. It provides a researcher an opportunity to apply his own concepts in different research contexts to the concerned area of study. The study included the survey of concerning literature which helps a researcher to review and build upon the work already done by others. Secondary Data was obtained from various sources such as books, research papers, magazines, journals and e-resources.

\section{OVERVIEW OF ICT ENABLED EDUCATION}

The Information and Communication Technology (ICT) is an umbrella term that includes any communication device or application encompassing: radio, television, cellular phones, computer, and network hardware and software, satellite 
systems and so on, as well as the various services and applications associated with them, such as videoconferencing and distance learning. When such technologies are used for educational purposes, namely to support and improve the learning of students and to develop learning environments, ICT can be considered as a subfield of Educational Technology. ICT in higher education are being used for developing course material; delivering content and sharing content; communication between learners, teachers and the outside world; creation and delivery of presentation and lectures; academic research; administrative support, student enrolment etc. In the current information society, people have to access knowledge via ICT to keep pace with the latest developments. In such a scenario, education, which always plays a critical role in any economic and social growth of a country, becomes even more important. Education not only increases the productive skills of the individual but also his/her earning power. It gives them a sense of well-being as well as capacity to absorb new ideas, increases their social interaction, gives access to improved health and provides several more intangible benefits. The various kinds of ICT products available and having relevance to education, such as teleconferencing, email, audio conferencing, television lessons, radio broadcasts, interactive radio counselling, interactive voice response system, audiocassettes and CD ROMs have been used in education for different purposes Today ICTs - including laptops wirelessly connected to the Internet, personal digital assistants, low cost video cameras and cell phones have become affordable, accessible and integrated in large sections of the society throughout the world. It can restructure organizations, promote collaboration, increase democratic participation of citizens, improve the transparency and responsiveness of governmental agencies, make education and health care more widely available, foster cultural creativity and enhance the development in social integration. It is only through education and the integration of ICT in education that one teaches students to be participants in the growth process in this era of rapid change. ICT also allows for the creation of digital resources like digital libraries where students, teachers and professionals can access research material and course material from any place at any time. Such facilities allow the networking of academics and researchers and hence sharing of scholarly material.

In view of ICT, education can be classified into three main categories:

1. E-learning

2. Blended Learning

3. Distance Learning

\section{E-Learning}

Electronic learning is a general term used to refer to computerenhanced learning. It is commonly associated with the field of advanced learning technology (ALT), which deals with both the technologies and associated methodologies in learning using networked and/or multimedia technologies. It is also known as Online Learning. Distance education provided the base for e-learning's development. E-learning can be 'on demand'. It overcomes timing, attendance and travel difficulties. E-learning allows delivery, dialogue and feedback over the internet. It allows mass customization in terms of content and exams. E-education can provide access to the best teachers and the best practices or knowledge available. It is possible to leverage the online environment to facilitate teaching techniques like role-play across time and distance. It can also facilitate the development of scenarios, which can be rarely witnessed in practice. ICT can play a valuable role to monitor and log the progress of the students across time, place and varied activities. E-learning allows higher participation and greater interaction. It challenges the concept that face-toface traditional education is superior to it. The web and the internet is the core ICTs to spread education through elearning. The components include e-portfolios, cyber infrastructures, digital libraries and online learning object repositories. All the above components create a digital identity of the student and connect all the stakeholders in the education process.

\section{Blended Learning}

It is the combination of multiple approaches to learning. It is usually used to define a situation where different delivery methods are combined together to deliver a particular course. These methods may include a mixture of face-to-face learning, self-paced learning and online classrooms.

Face to face Learning refers to learning that occurs in a traditional classroom setting where a faculty member delivers instruction to a group of learners. This could include lectures, workshops, presentation, tutoring, conference and much more.

Self-paced Learning provides the flexibility to learn according to the availability of learners' own time and pace. It occurs in a variety of ways such as: reading specific chapters from text book, studying course material presented through web-based or $\mathrm{CD}$ based course, attending pre-recorded classes or sessions, reading articles referred by faculty members, working on assignments $\backslash$ projects and searching the internet. Online Collaborative Learning involves interaction between learners and faculty members through the web. This interaction can occur in one of the following modes: Synchronous interaction and Asynchronous interaction.

Synchronous means 'At the same time'. It involves interacting with a faculty member and other learners via the web in real time using technologies such as virtual classrooms and / or chat rooms. On the other hand, Asynchronous means 'Not at the same time'. It enables learners to interact with their colleagues and faculty members at their own convenience, such as interacting through email.

\section{Distance Learning}

It is a type of education, where students work on their own at home or at the office and communicate with faculty and other students via e-mail, electronic forums, videoconferencing, chat rooms, instant messaging and other forms of computerbased communication. It is also known as 'Open Learning'. Most distance learning programs include a computer based training (CBT) system and communication tools to produce a virtual classroom. Since the Internet and the World Wide Web are accessible from virtually all computer platforms, they serve as the foundation for many distance learning systems.

\section{DISCUSSION AND OUTCOMES}

Objective 1: To study the impact of ICT on Teaching in Higher Education with reference to India

India is making use of powerful combination of ICTs such as open source software, satellite technology, local language interfaces, easy to use human-computer interfaces, digital libraries etc. with a long-term plan to reach the remotest of the villages. Community service centers have been started to promote e-learning throughout the country. Notable initiatives of use of ICT in education in India include institutions such as Indira Gandhi National Open University (IGNOU), IIT-Kanpur, IIT-Bombay, UGC etc. The most important dimension of higher education sector influenced by ICT integration is improving quality of teaching. The integration of ICTs would not only help in promoting personal growth but also in developing 'knowledge societies'. Conventional teaching-learning processes are undergoing a paradigm shift. Focus of instruction is now on education programs/practices that promote competency and performance. Such curricula tends to require access to variety of information sources, information 
forms and types; student centered learning settings based on information access and inquiry; learning environments centered or problem-centered and inquiry-based activities, authentic settings and examples; and teachers as coaches and mentors rather than content experts. The shift towards development of educational programs is well supported and encouraged by the emerging instructional technologies. Technology facilitated learning would result in preparation of staff regarding innovative pedagogic methods, new ways of learning and interacting, easy sharing of new practices among teaching community and result in widening the opportunities for their participation. The capabilities of competent and trained teachers/academic experts can be made available to larger audiences/students through flexible and virtual settings. The inclusion of learning tools, easier use of multimedia or simulation tools, easy and almost instant access to data and information in a digital form which allows for computations and data processing generates possibilities which were otherwise not feasible. The possibility to diffuse these innovations and complement the learning content to improve quality of teaching through innovative pedagogic methods is high in India.

\section{Objective 2: To analyze the opportunities and challenges of integration of ICT in higher education}

The changes taking place due to globalization and internationalization attach premium to knowledge and information. Life-long learning has become the driving force to sustain in the contemporary competitive environment. Therefore, to strengthen this knowledge-driven growth, new technologies, skills and capabilities are needed. Apart from enhancing student's learning experience, role of ICT in capacity building/training of educational personnel has very large potential. National level institutes can provide leadership role in enhancing technical and managerial manpower in different disciplines through ICT networks and collaborations. ICT has the potential to drive innovative and effective ways of teaching-learning and research. While using ICT in education has some obvious benefits, ICT also bring challenges. First is the high cost of acquiring, installing, operating, maintaining and replacing ICTs. While potentially of great importance, the integration of ICT into teaching is still in its infancy. Introducing ICT systems for teaching in developing countries has a particularly high opportunity cost because installing them is usually more expensive in absolute terms than in developed countries. The four most common mistakes in introducing ICT into teaching are i) installing learning technology without reviewing student needs and content availability; ii) imposing technological systems from the top down without involving faculty and students; iii) using inappropriate content from other regions of the world without customizing it appropriately; and iv) producing low quality content that has poor instructional design and is not adapted to the technology in use. Although ICT offers a whole lot of benefits, there are some risks of using ICT in education.

\section{Objective 3: To explore the role of ICT in improving the} quality of higher education

Swift growth of ICT is taking place all over the world. They have emerged as powerful tools for diffusion of knowledge and information. Their introduction and unprecedented use in higher education has generated varied response. Presence of ICT in education sector is increasing steadily. In spite of the fact that education is a social enterprise and teachers are the traditionally mainstay of teaching learning process, ICTs are a powerful tool for diffusing knowledge and information, a fundamental aspect of the education process. ICTs can play enormous role for improving access and equity in education sector in general and higher education sector in particular. ICT lend themselves as an ideal mechanism to bridge the gap by complementing both formal education system as well as distance learning systems. E-learning is emerging as an important strategy to provide widespread and easy access to quality higher education in India. Another most important dimension of higher education sector influenced by ICT integration is improving quality of teaching-learning. Conventional teaching-learning processes are undergoing a paradigm shift which is supported by the integration of ICT to deliver information to students.

Apart from enhancing student's learning experience, role of ICT in training of educational personnel has very large potential. ICT has the potential to drive innovative ways of teaching-learning and research. The focus on ICT to back quality research through utilization of rigorous research methodology and in-depth analysis is critical for the growth of higher education in India. Therefore, ICT has an important role in improving the quality of higher education in India.

\section{CONCLUSION}

The use of technology in education is increasingly being perceived as a major catalyst in changing the way higher education institutions perform their core functions. This change includes, amongst other things, change in styles of teaching as a result of the introduction of new instructional artifacts, change in students' approaches to learning and change in the way information and educational materials are accessed. Notwithstanding this ubiquity of ICT in higher education institutions, empirical evidence suggests that its use for academic purposes remains minimal when one compares the latter to other uses. This strikes a chord with the scenario at various higher education institutions in India. The onus is on the institutions to ensure that its academic culture promotes the use of ICT in teaching and learning. This necessarily calls for a steady break away from the overreliance on traditional chalk and talk method of teaching to a more blended one that would see ICT being incorporated into instruction. Holding onto the aforesaid traditional way of knowledge dissemination is to assume that there is a one-sizefit all approach in teaching and learning, a presumption that is further from reality. ICT has the potential to remedy this as it provides for the different learning styles of students and affords the latter a chance to progress academically. As it has been said already, teachers wield immense power in influencing the learning approaches of students. Therein, lies a significant opportunity to influence students to use ICT in their studies. Dealing with faculty needs would undoubtedly be the first step towards achieving this end. A lot has to be done to internally market the importance of using ICT in teaching and then designing course materials that will impel learners and lecturers to use it in one way or another. Although, presently the initiatives for integrating ICT in higher education institutions in India are continuing in a sporadic manner, UGC is advocating and making efforts to enhance the quality of higher education by framing policy guidelines for their integration in classroom and other activities. The need of the hour is the need to provide education for everyone, anywhere and anytime. This is possible only by effective integration of ICT which can help many (including marginalized groups) to access higher education in India.

\section{REFERENCES}

1. Bhattacharya, I., Sharma, K. (2007). "India in the Knowledge Economy- An electronic paradigm", International Journal of Educational Management, vol. 21 , issue 6, pp. 543-568.

2. Bottino, R. M. (2003). "ICT, National Policies and Impact on Schools and Teachers' Development", Proceedings of the working groups conference on International federation for information processing, Australian Computer Society, Darlinghurst, Australia, pp 3-6.

3. Creswell, John W. (2003). "Research Design: Qualitative, Quantitative and Mixed Method Approaches", 2nd edition, New York: Sage Publications.

4. Cross, M., Adam, F. (2007). "ICT Policies and Strategies in Higher Education in South Africa: National and Institutional Pathways", Higher Education Policy, vol. 20, issue 1, pp. 73-95.

5. Kothari, C.R. (1990). "Research Methodology", 2nd edition, New Delhi: New Age International Publications.

6. Kozma, R. (2005). "National Policies That Connect ICT-Based Education Reform to Economic and Social Development", Human Technology, vol.l, issue 2, pp 117-156. 
7. Lalitbhushan,S., Jagzape, Arunita T., Raweker, Alka T. (2014). "Role of Information Communication Technology in Higher Education: Learners perspective in rural medical schools". Journal of Clinical and Diagnostic Research, vol. 4, issue 5, pp 163-169.

8. Lim, C. P., Hang, D. (2003). "An Activity Theory Approach to Research of ICT Integration in Singapore Schools", Computers \& Education, vol. 41, issue 1, pp 49-63.

9. Manisha, Anju. (2014). "The Role of ICT in Higher Education in India", International Journal of Enhanced Research in Management and Computer Application, vol. 3, issue 11, pp 16-19.

10. Mason, R. (2000). "From Distance Education to Online Education", The Internet and Higher Education, vol. 3, issue 2, pp 63-74.

11. Mc Gorry, S. Y. (2002). "Online, but on target? Internet based MBA courses: A case study", The Internet and Higher Education, vol. 5, issue 2, pp 167-175.

12. Meredith, D., Borg, Walter, R., Gall, Joyce P. (1996). "Educational Research: An Introduction", 6th edition, New York: Longman Publications.

13. Mishra, S., Sharma, R. C. (2005). "Development of e-Learning in India", University News, vol. 43, issue 11, pp 14-20.

14. Mondal, Ajit., Jayanta. (2012). "ICT in Higher Education", Bhatter College Journal of Multidisciplinary studies, vol. 4, issue 5, pp 123-130. 